\title{
STUDI MODEL INTERAKSI PENGELOLAAN PROGRAM KB LINI LAPANGAN
}

\author{
Menara Simanjuntak; Lim Sanny \\ Management Department, School of Business Management, BINUS University \\ Jln. K. H. Syahdan No. 9, Palmerah, Jakarta Barat 11480 \\ menara0110@yahoo.com; lsanny2004@yahoo.com
}

\begin{abstract}
Interaction model of family planning program management field lines are enhanced as one objective of family planning program revitalization. This research was conducted by exploration activities with qualitative approach (in-depth interviews and group discussion forums) for reconstructing a "model of enhanced interaction". The basic concept of enhanced interaction models are built based on the concept of empowerment, coordination, accompaniment, financing through civil society organizations and the Government of DKI Jakarta. Improvements made to the enhanced interaction models are in the field of family planning services. This study aims to improve the effectiveness of the implementation of the national family planning program and the implementation of the program of economic empowerment of the family in the long-term periods characterized by interaction changes of family planning program management team in the district level and the executive of family planning program in the village level effectively and efficiently. In order to improve the cultivation of family planning program field line, it is necessary to improve the status of Village Family Planning Executive Team to become Village Family Planning Management Team as a more effective management approach. This study recommends that the Government of DKI Jakarta to support operational costs and Activity Groups in RW level. The expected impact is the increase of the proportion of active family planning participants towards PUS in the area of research, especially for pre-prosperous Families and prospreous-I families (Poor). Poor families who join family planning program have the priority access to poverty reduction through economic empowerment of the family planning participants, and it is expected to be implemented in the province of Jakarta.
\end{abstract}

Keywords: interaction model, family planning program management, family planning program revitalization, economic family empowerment, vice patron of family planning program

\begin{abstract}
ABSTRAK
Model interaksi pengelolaan program keluarga berencana lini lapangan yang disempurnakan sebagai salah satu sasaran revitalisasi program KB. Penelitian ini melakukan kegiatan eksplorasi dengan pendekatan kualitatif (wawancara mendalam dan forum diskusi kelompok) untuk dapat menyusun kembali suatu "model interaksi yang disempurnakan" (MIDI). Konsep dasar model interaksi yang disempurnakan tersebut dibangun berdasarkan konsep pemberdayaan, koordinasi, pendampingan, pembiayaan melalui swadaya masyarakat dan Pemda DKI Jakarta. Penyempurnaan dilakukan terhadap MIDI tersebut dalam bidang Pelayanan KB. Tujuan untuk meningkatkan efektifitas pelaksanaan program KB Nasional dan pelaksanaan program pemberdayaan ekononomi keluarga jangka panjang yang ditandai dengan perubahan interaksi tim pengelola KB Kecamatan dan pelaksana KB Kelurahan secara efektif dan efisien. Guna meningkatkan penggarapan KB lini lapangan, dipandang perlu meningkatkan status Tim Pelaksana KB Kelurahan menjadi Tim Pengelola KB Kelurahan sebagai suatu pendekatan manajemen yang lebih efektif. Penelitian ini merekomendasikan agar Pemda DKI Jakarta memberikan dukungan biaya operasional PPKB-RW dan Kelompok-Kelompok Kegiatan yang ada di RW. Dampak yang diharapkan adalah peningkatan proporsi peserta KB aktif terhadap PUS di wilayah penelitian, terutama bagi Keluarga Pra Sejahtera dan Keluarga Sejahtera-I (Miskin). Keluarga miskin yang ber-KB tersebut diprioritaskan mendapat akses pengentasan kemiskinan melalui pemberdayaan ekonomi keluarga peserta KB dan diharapkan dapat diimplementasikan pada Wilayah Provinsi DKI Jakarta.
\end{abstract}

Kata kunci: Model interaksi, Pengelola program KB, Revitalisasi Program KB, Pemberdayaan ekonomi keluarga, Pembantu Pembina KB 


\section{PENDAHULUAN}

Para Pengendali Program Lapangan Keluarga Berencana (PPLKB) maupun Penyuluh Keluarga Berencana (PKB) pada masa lampau sangat piawai melibatkan banyak pihak yang membantu melaksanakan kegiatan penerangan dan motivasi, melakukan kunjungan rumah untuk mengajak pasangan usia subur (PUS) ber-KB serta pembinaannya. Pihak-pihak yang terlibat langsung di tingkat kecamatan tergabung dalam tim pengelola seperti Camat, Tim Penggerak PKK Kecamatan, dan Puskesmas Kecamatan yang diketuai Camat. Sedangkan tim pelaksana KB ditingkat Kelurahan/Desa diketuai Lurah/Kepala Desa bersama anggota lainnya seperti Tim Penggerak PKK Kelurahan, Ka.Puskesmas Kelurahan, Pembantu Pembina KB (PPKB-RW) Tim PKK-RW, Kader Posyandu, serta Tokoh Masyarakat dan Tokoh Agama.

Masalah yang nyata dihadapi dalam pelaksanaan program KB pada era Otonomi Daerah ini adalah lebih dari separuh dari sekitar 50.000 Penyuluh KB seluruh Indonesia pada 1997 tinggal sekitar 21.000 PKB pada 2010. Sebagian besar telah pindah tugas ke instansi lain, dan hampir 12 tahun tidak ada Penyuluh KB baru pengganti yang pindah, maupun telah purnatugas. Kemudian sebagai konsekuensi dari Otonomi Daerah, maka instansi vertikal BKKBN menjadi terputus dan masingmasing Provinsi, Kabupaten/Kotamadya membentuk Unit Satuan Kerja yang merupakan gabungan yang bervariasi seperti Dinas Kependudukan Catatan Sipil dan KB, Dinas Pemberdayaan Masyarakat Perempuan, dan KB dan sebagainya. Dengan sendirinya keadaan ini berimbas pada kinerja program KB Nasional yang semakin sulit menambah proporsi jumlah peserta KB aktif terhadap jumlah pasangan usia subur untuk menurunkan laju pertumbuhan penduduk alami untuk mendekati 1 persen. Pada kenyataannya, berdasarkan Sensus Penduduk 2010, laju pertumbuhan penduduk (LPP) naik dari 1,20 persen menjadi 1,39 persen di DKI Jakarta, dan secara Nasional dari 1,43 menjadi 1,49 persen pada 2000-2010.

Kesulitan untuk menaikkan persentase peserta KB aktif terhadap PUS tersebut karena setiap tahunnya selalu terdapat peserta KB yang drop-out atau pemakaian yang terhenti dengan berbagai alasan: ingin anak pertama, ingin menambah jumlah anak, lupa menelan pil, lupa suntikan ulangan, lupa pakai kondom serta alasan logistik. Sedangkan upaya mencapai peserta KB baru yang benarbenar baru semakin tidak mudah sejak awal reformasi (1997). Persentase Peserta KB aktif tersebut terhadap PUS harus dipertahankan tetap berada pada posisi diatas 60 persen, dan jika memungkinkan bertambah lagi supaya daya ungkit dan pengaruhnya signifikan terhadap pengendalian pertumbuhan penduduk alami sekitar 1 persen per tahun di DKI Jakarta.

Upaya peningkatan kualitas kesertaan KB dengan menggunakan kontrasepsi jangka panjang (IUD, MOP, MOW, dan Implan) yang proporsinya baru sepertiga atau sebesar 32,4 persen. Sehingga, diharapkan pada tahun-tahun mendatang secara kuantitas mampu mendominasi pemakaian kontrasepsi dibanding pemakaian 67,6 persen metode sederhana seperti pil, suntik, dan kondom yang lebih mudah terputus pemakaiannya (drop out).

Sasaran upaya ini adalah untuk lebih lama mempertahankan tingkat kelangsungan (continuation rate) pemakaian alat atau mengikuti metode tersebut. Upaya lain yang tengah dilakukan adalah melalui pendekatan personal dan keluarga dari rumah-rumah serta tidak cukup dilakukan hanya satu kali, karena harus dilakukan konsultasi yang matang dengan menggunakan media Komunikasi, Informasi, dan Edukasi (KIE-Kit), meningkatkan kemudahan, kemurahan dan kenyamanan serta kecepatan pelayanan. Sedangkan bagi pemakai kontrasepsi pil, suntik dan kondom ditekankan dari segi pembinaan dan dukungan logistik yang efektif. 
Tabel 1 Pencapaian Peserta KB Aktif DKI Jakarta Tahun 2010

\begin{tabular}{lrr}
\hline \multicolumn{1}{c}{ Mix Kontrasepsi yang Dipakai Akseptor } & Jumlah & \multicolumn{2}{c}{$\begin{array}{c}\text { Peserta Mix } \\
\text { Pemakaian Kontrasepsi }\end{array}$} \\
Pil & 261.794 & 26,32 \\
Kondom & 24.234 & 2,43 \\
Suntikan & 384.381 & 38,65 \\
IUD & 211.913 & 21,31 \\
Implan & 66.757 & 6,71 \\
MOP & 10.941 & 1,10 \\
MOW & 34.535 & 3,47 \\
Jumlah Peserta KB Aktif & $\mathbf{9 9 4 . 4 5 5}$ & $\mathbf{1 0 0 , 0 0}$ \\
Jumlah Pasangan Usia Subur (PUS) & $\mathbf{1 . 6 3 0 . 2 5 4}$ & - \\
Persentase Peserta KB Aktif terhadap PUS & $\mathbf{6 1 , 0 7}$ & - \\
\hline
\end{tabular}

(Sumber: Badan Pemberdayaan Masyarakat, Perempuan, dan Keluarga Berencana Provinsi DKI Jakarta, 2010)

Dari data Provinsi DKI Jakarta tersebut, terlihat bahwa peserta KB pemakai kontrasepsi jangka panjang (IUD, MOP, MOW, Implan) masih rendah $(31,50 \%)$ sedangkan yang ideal di atas $50 \%$. Kesertaan pria dalam ber-KB masih rendah yaitu 3,53\%, padahal pada 2010 ini ditargetkan secara nasional sebesar $4 \%$. Di sisi lain, terkait dengan pemakaian keempat metode KB jangka panjang tersebut juga harus dapat dilakukan penanggulangan komplikasi ringan maupun berat yang harus dirujuk ke tempat pelayanan (PKM, RS, Klinik KB) untuk dilakukan medis pelayanan KB. Persentase peserta KB yang mengalami komplikasi tersebut sangat kecil (1:20.000), namun meskipun sangat kecil, justru di situlah letaknya Critical Success Factor program KB dewasa ini. Sebagai bentuk pengayoman dan jaminan bagi peserta $\mathrm{KB}$ sekaligus menghindari rumors yang berpengaruh negatif terhadap program KB tersebut, maka targetnya kurang dari 24 jam harus sudah dilayani sehingga tim pengelola KB Kecamatan tersebut harus siaga selama 24 jam termasuk pada hari libur.

Pola penggarapan program hampir tidak berkembang sejak 12 tahun lalu. Jumlah penyuluh KB semakin berkurang menjadi 458 orang dibanding 12 tahun sebelumnya, sebanyak lebih dari 600 orang. Jumlah kader dan PPKB-RW yang tidak aktif semakin banyak karena sudah lanjut usia dan meninggal dunia. Sedangkan merekrut kader/relawan baru semakin sulit dan semakin jarang yang bersedia, pelatihan kader baru juga sudah tidak pernah dilakukan. Revitalisasi program KB sejak beberapa tahun lalu dikumandangkan Presiden RI setiap Hari Keluarga Nasional, namun baru dalam tataran konsep yang penghalangnya cukup banyak terutama perubahan era sentralisasi ke era Otonomi Daerah. Hal itu menyebabkan BKKBN Pusat semakin sulit mengembangkan strategi penggarapan program KB menyeluruh yang digulirkan secara vertikal. Unit Satuan Kerja di Kabupaten Kotamadya yang dahulu merupakan unit tersendiri bergabung dengan berbagai urusan lainnya yang satu rumpun seperti Kependudukan, Catatan Sipil, Pemberdayaan Masyarakat dan Pemberdayaan Perempuan.

Tim peneliti sepakat ingin merajut kembali pola interaksi tim pengelola dan pelaksana KB lini lapangan tersebut. Tim merancang penyempurnaan model interaksi yang lebih sesuai dengan perubahan yang dialami dan perkembangan zaman, sekaligus mengatasi kelangkaan tenaga PKB yang terus makin berkurang maupun perubahan koordinasi yang terpusat menjadi desentralisasi. Adapun tujuan penelitian ini adalah terbangunnya model interaksi tim pengelola dan pelaksana program KB lini lapangan (Kecamatan dan Kelurahan) yang disempurnakan dengan mengefektifkan peran unit pengelola dan pelaksana, institusi masyarakat, kader, dan tokoh masyarakat atas dasar konsep pemberdayaan, koordinasi, pendampingan, dan konsultasi dalam penggarapan program KB untuk meningkatkan pelayanan yang berkualitas kepada Keluarga Prasejahtera dan Keluarga Sejahtera I (miskin) di perkotaan maupun pedesaan.

Hasil studi ini diharapkan dapat diimplementasikan di Wilayah Provinsi DKI Jakarta, dan dipublikasikan melalui seminar maupun jurnal ilmiah berskala nasional dan internasional. 


\section{Landasan Teori}

Sosiologi sebagai ilmu pengetahuan mempunyai beberapa objek (Henslin, 2002). Objek material sosiologi adalah kehidupan sosial, gejala-gejala dan proses hubungan antara manusia yang memengaruhi kesatuan manusia itu sendiri. Objek formal sosiologi lebih ditekankan pada manusia sebagai makhluk sosial atau masyarakat. Dengan demikian objek formal sosiologi adalah hubungan manusia antara manusia serta proses yang timbul dari hubungan manusia di dalam masyarakat.

Hampir semua gejala sosial yang terjadi di desa maupun di kota, baik individu ataupun kelompok, merupakan ruang kajian yang cocok bagi sosiologi, asalkan menggunakan prosedur ilmiah. Ruang lingkup kajian sosiologi lebih luas dari ilmu sosial lainnya. Hal ini dikarenakan ruang lingkup sosiologi mencakup semua interaksi sosial yang berlangsung antara individu dengan individu, individu dengan kelompok, serta kelompok dengan kelompok di lingkungan masyarakat. Interaksi sosial merupakan hubungan tersusun dalam bentuk tindakan berdasarkan norma dan nilai sosial yang berlaku dalam masyarakat. Berdasarkan Henslin (2002), faktor-faktor yang mendasari proses terbentuknya interaksi sosial adalah sebagai berikut.

Imitasi, yaitu proses sosial atau tindakan seseorang untuk meniru orang lain, baik sikap penampilan, gaya hidup, bahkan apa saja yang dimilikinya. Imitasi pertama kali muncul di lingkungan keluarga, kemudian lingkungan tetangga dan lingkungan masyarakat. Identifikasi, adalah upaya yang dilakukan oleh seorang individu untuk menjadi sama (identik) dengan individu lain yang ditirunya. Proses identifikasi tidak hanya terjadi melalui serangkain proses peniruan pola perilaku saja, tetapi juga melalui proses kejiwaaan yang sangat mendalam. Sugesti, adalah rangsangan, pengaruh, stimulus yang diberikan seseorang individu kepada individu lain sehingga orang yang diberi sugesti menuruti atau melaksanakan tanpa berpikir kritis dan rasional. Motivasi, yaitu rangsangan pengaruh, stimulus yang diberikan seorang individu kepada individu lain, sehingga orang yang diberi motivasi menuruti tahu melaksanakan apa yang dimotivasikan secara kritis, rasional, dan penuh rasa tanggung jawab. Simpati, adalah proses kejiwaan, bahwa seorang individu merasa tertarik kepada seseorang atau kelompok orang, karena sikapnya, penampilannya, wibawanya, atau perbuatannya yang sedemikian rupa. Empati, yaitu mirip dengan simpati, tetapi tidak semata-mata perasaan kejiwaan saja. Empati dibarengi dengan perasaan organisme tubuh yang sangat intens/dalam.

Organisasi menurut Robbins (2005) adalah susunan yang dibentuk oleh orang-orang untuk mencapai suatu tujuan. Sebuah organisasi dapat terbentuk karena dipengaruhi oleh beberapa aspek seperti penyatuan visi dan misi serta tujuan yang sama dengan perwujudan eksistensi sekelompok orang tersebut terhadap masyarakat. Dalam pelaksanaan program KB dan program pemberdayaan ekonomi keluarga di lini lapangan (kecamatan dan kelurahan) hingga dewasa ini masih tetap melibatkan partisipasi berbagai pihak sektoral terkait maupun partisipasi institusi masyarakat itu sendiri. Pengorbanan ataupun sumbangan dalam partisipasi tersebut baik berupa tenaga, waktu, pemikiran bahkan materi untuk mencapai keberhasilan kedua program tersebut. Pada dasarnya partisipasi didefinisikan sebagai keterlibatan mental atau pikiran dan emosi atau perasaan seseorang di dalam situasi kelompok yang mendorongnya untuk memberikan sumbangan kepada kelompok dalam usaha mencapai tujuan serta turut bertanggung jawab terhadap usaha yang bersangkutan. Ada tiga buah unsur penting yang menurut Davis (1962) memerlukan perhatian khusus dalam partisipasi.

Unsur pertama, bahwa partisipasi atau keikutsertaan sesungguhnya merupakan suatu keterlibatan mental dan perasaan, lebih daripada semata-mata atau hanya keterlibatan secara jasmaniah. Unsur kedua adalah kesediaan memberi sesuatu sumbangan kepada usaha mencapai tujuan kelompok. Ini berarti, bahwa terdapat rasa senang, kesukarelaan untuk membantu kelompok.Unsur ketiga adalah unsur tanggung jawab. Unsur tersebut merupakan segi yang menonjol dari rasa menjadi anggota. Hal ini diakui sebagai anggota artinya ada rasa memiliki (sense of belonging). 
Davis juga mengemukakan jenis-jenis partisipasi, yaitu sebagai berikut: (a) Pikiran (psychological participation), (b) Tenaga (physical partisipation), (c) Pikiran dan tenaga (psychological participation dan physical partisipation), (d) Keahlian (participation with skill), (e) Barang (material participation), dan (f) Uang (money participation). Graham (2008) mengatakan bahwa ada metode baru untuk mengidentifikasi interaksi sosial dengan menggunakan batasan kondisi yang berbeda. Metode tersebut memberikan estimasi yang konsisten dengan multihubungan sosial berupa interaksi sosial dalam bentuk garis lurus (Manski, 1993). Ketika interaksi sosial tidak searah bentuk garis lurus dengan perkiraan dalam kondisi tetap dan meneruskan pengukuran dengan pengujian yang konsisten tidak akan ada interaksi sosial walaupun menggunakan sampel yang besar. Bayer dan Ross (2006) mengatakan bahwa kota dan sekitarnya (suburbs) menyediakan rumah, tempat bekerja, fasilitas lingkungan sosial, dan pendidikan kepada banyak individu dan keluarga dalam suatu kesatuan, bahkan strata sosial yang terdiri dari berbagai ras, etnik, kelompok ekonomi.

Suatu teori baru didasarkan pada titik persimpangan konseptual antara teori pertukaran dan teori identitas (Brown, 2006). Walaupun kedua teori memiliki penekanan yang berbeda digunakan dalam topik-topik penelitian, kedua interaksi sosial tersebut mempelajari dan memahami banyak fenomena yang sama melalui kacamata yang berbeda. Pengamatan yang lebih dekat dari teori yang berbeda menunjukkan bahwa mereka dapat saling melengkapi dan bukan bersaing dalam rangka pemahaman, perilaku, dan struktural konsekuensi kognitif dari interaksi sosial.

Lebih lanjut jika ingin memahami lebih dalam tentang model interaksi tim pengelola dan tim pelaksana program KB lini lapangan, kiranya latar belakang yang berbeda dari anggota tim dewasa ini tidak untuk dipertentangkan jika mereka dapat saling melengkapi. Tim menurut Robbins dan Judge (2007) merupakan kelompok yang upaya-upaya individunya menghasilkan suatu kinerja yang lebih besar daripada jumlah dari masukan-masukan individual. Organisasi selalu mengharapkan sinergi para anggotanya, sehingga salah satu ciri organisasi modern adalah tidak ada lagi orang yang bekerja sendiri melainkan bekerja dalam tim. Tim yang bersinergis tentu melalui proses sosial dan interaksi sosial seperti diuraikan di atas. Menurut Yukl (2001) kata tim biasanya mengacu pada sebuah kelompok tugas yang kecil yang para anggotanya memiliki tujuan yang sama, peran yang saling bergantung pada keterampilan yang saling melengkapi. Interaksi sosial tersebut pada umumnya dilakukan melalui komunikasi diantara anggota tim. Komunikasi menurut Dixon (1996) adalah pengiriman dan pemahaman dari suatu yang berarti. Komunikasi yang baik jika pengirim dan penerima saling mengerti apakah melalui suara, bahasa yang dimengerti, bahasa tubuh (body language), tanda-tanda/simbol-simbol, bunyi-bunyian, atau tertulis dan yang dikirim melalui media seperti telepon, e-mail, faksmile, dan sebagainya. Robbins dan Judge (2007) menyatakan bahwa fungsi komunikasi ada empat, yaitu: mengendalikan perilaku, memotivasi, mengungkapkan perasaan, dan informasi. Komunikasi interpersonal atau komunikasi di antara dua atau lebih manusia. Peranan komunikasi dalam kerangka interaksi sosial maupun dalam rangka kerja sama tim adalah sangat penting dan sangat menentukan keberhasilan suatu tim dalam mencapai sasaran atau tujuannya. Komunikasi menyampaikan informasi, dan dewasa ini dengan perkembangan teknologi informasi dan komunikasi yang begitu cepat berubah. Seperti yang dikemukakan oleh O’Brien (2006) bahwa teknologi telekomunikasi yang paling cepat berubah baik melalui komputer maupun melalui telepon selular (HP). Teknologi informasi seperti komputer dan alat-alat komunikasi tersebut begitu cepat diadopsi dan digunakan sebagian besar organisasi, kelompok, tim, keluarga dan individu. Dewasa ini dikenal tim virtual yang para anggotanya menggunakan internet, intranet, ekstranet, dan jaringan lainnya untuk berkomunikasi, berkoordinasi, dan bekerja sama satu sama lain dalam tugas atau proyek dan mereka dapat bekerja di geografis yang berbeda dan bahkan untuk organisasi yang berbeda (Brien, 2006).

Masih cukup banyak orang mengingat bahwa sukses Indonesia pada era 80-90-an antara lain di bidang KB dan Pertanian. Di bidang Keluarga Berencana Indonesia berhasil menurunkan Angka Kelahiran Total Rata-rata per wanita kawin dari 5,6 anak menjadi 3,2 anak per wanita kawin, yang artinya rata-rata seorang ibu memiliki sekitar 3 anak dan khusus di DKI Jakarta, Yogyakarta, Bali 
mencapai sekitar 2 anak, sehingga memengaruhi secara signifikan laju pertumbuhan penduduk di Indonesia yang saat ini diperkirakan sekitar 2,3 persen per tahun (International Demography and Health Survey, UNFPA,BPS, 1991-2007). Reward atas keberhasilan tersebut BKKBN dianugerahi Global Management Award on Family Planning oleh UNFPA.

\section{METODE PENELITIAN}

Penelitian ini merupakan penelitian eksploratif, karena penelitian tentang model interaksi antara tim pengelola dan tim pelaksana program KB belum pernah dilakukan. Masih sangat sedikit penelitian yang mendalami tentang interaksi sosial dalam pelaksanaan program secara nasional. Oleh sebab itu, tim peneliti memutuskan menggunakan pendekatan kualitatif untuk mengungkap banyak hal yang perlu didalami dan diteliti masa mendatang.

Penelitian kualitatif dilakukan dengan wawancara mendalam (indepth interview) serta diskusi kelompok terpusat (focus group discussion) pada peran masing-masing pihak dalam penggarapan program KB maupun program pemberdayaan ekonomi keluarga. Penelitian kualitatif adalah tradisi tertentu dalam ilmu pengetahuan sosial yang secara fundamental bergantung pada pengamatan pada manusia dalam kawasannya sendiri dan berhubungan dengan orang-orang tersebut dalam bahasanya dan peristilahannya. Bogdan dan Taylor (1984) mendefinisikan metodologi kualitatif sebagai pendekatan yang diarahkan pada latar dan individu secara holistik (utuh) (Moleong, 2002). Pendekatan kualitatif digunakan karena ingin mendapatkan informasi mendalam mengenai gambaran model interaksi yang terjadi saat ini di antara tim pengelola dan pelaksana KB lini lapangan (Kecamatan dan Kelurahan).

Model adalah rencana, representasi, atau deskripsi yang menjelaskan suatu objek, sistem, atau konsep, yang sering kali berupa penyederhanaan atau idealisasi. Model, prototipe, purwarupa, atau arketipe adalah bentuk awal (contoh) atau standar ukuran dari sebuah entitas. Dalam bidang desain, sebuah prototipe dibuat sebelum dikembangkan atau justru dibuat khusus untuk pengembangan sebelum dibuat dalam skala sebenarnya atau sebelum diproduksi secara massal (Henslin, 2002).

\section{HASIL DAN PEMBAHASAN}

\section{Rumusan Hasil Wawancara Mendalam}

Berdasarkan hasil wawancara mendalam dengan Tim Pengelola KB Kecamatan dan Tim Pelaksana KB Kelurahan, dirumuskan hal-hal sebagai berikut. Pertama, peranan Tim Pengelola KB Kecamatan hanya memfasilitasi kegiatan pengarapan KB di lini lapangan yaitu Kelurahan dan RW. Intensitas kegiatan mulai ditemukan di tingkat Kelurahan yaitu melalui peranan Penyuluh KB dan Puskesmas Kelurahan. Jangkauan operasional lapangan kelihatannya semakin banyak bergantung pada operasional kegiatan PPKB RW beserta para Kader Kelompok-Kelompok Kegiatan yang ada di RW. Kedua, jenjang pemerintahan paling rendah di DKI Jakarta adalah Kelurahan yang dipimpin oleh Lurah. Kemudian fungsi pemerintahan tersebut dibantu oleh institusi masyarakat yaitu RW dan RT. Jumlah penduduk yang banyak dan padat di DKI Jakarta rata-rata pada setiap RW terdapat sekitar 600 hingga 2.000 keluarga. Jumlah RW dalam satu Kelurahan berkisar 9 s/d 16 RW, tergantung pada luas dan jumlah penduduk. 
Tabel 1 Perbandingan Data Keluarga Kelurahan Kemanggisan dengan Pulogebang

\begin{tabular}{llrr}
\hline \multicolumn{1}{c}{ Karakteristik } & Kemanggisan & Pulogebang \\
\hline 1. & Jumlah Keluarga & 5.686 & 32.297 \\
2. & Jumlah Jiwa Dalam Keluarga & 21.444 & 97.826 \\
3. & Jumlah Keluarga Pra-S dan Sejahtera I & 944 & 2.414 \\
4. & Jumlah PUS & 3.763 & 14.981 \\
5. & Jumlah Peserta KB aktif & 2.963 & 11.918 \\
6. & Persentase Peserta KB Aktif/PUS & $78,74 \%$ & $79,55 \%$ \\
7. & Jumlah RW & 9 & 16 \\
8. & Jumlah PPKB-RW & 9 & 16 \\
9. & Jumlah RT & 114 & 181 \\
\hline
\end{tabular}

(Sumber: Kelurahan Kemanggisan dan Kelurahan Pulogebang)

Ketiga, model interaksi yang selama ini masih bergantung pada tim pengelola KB Kecamatan, padahal Kelurahan sudah memiliki perangkat dan sarana pelayanan KB yang lengkap, serta Lurah dan perangkatnya memiliki kompetensi sebagai Ketua Tim Pengelola KB Kelurahan yang dibantu dengan Institusi Masyarakat PPKB-RW serta kader-kader Kelompok Kegiatan yang ada di RW.

\section{Rumusan Focus Group Discussion}

Pertama, diskusi terfokus pada peranan PPKB-RW sangat terbuka, karena pada dasarnya ibuibu kader PPKB RW tersebut lebih banyak melakukan tugasnya berupa komunikasi, informasi, dan edukasi KB pada masyarakat dan keluarga di lingkungannya. Kedua, peran dan tugas PPKB-RW tersebut dapat dirumuskan sebanyak 10 peran sebagai pembantu ppembina KB di RW dengan dibantu oleh seluruh ibu-ibu kader Kelompok Kegiatan (BKB,BKR,BKL, UPPKS dan Posyandu).

\section{Diskusi Usulan Model Interaksi Pengelolaan KB Kelurahan}

Diskusi model dilakukan bersama BPMPKB Provinsi DKI Jakarta khususnya dengan Kabid Kesehatan Reproduksi dan Kabid Keluarga Sejahtera. Kemudian dengan Kepala Kantor KB Jakarta Barat dan Jakarta Timur dan dengan PPLKB Kecamatan Palmerah dan Kecamatan Cakung bersama Penyuluh KB yang bersangkutan. Hasil diskusi adalah sebagai berikut: penggarapan KB lini lapangan dalam penelitian ini agar lebih difokuskan pada Kelurahan dan Rukun Warga; peran Kecamatan, Kotamadya dan Provinsi adalah memperlancar dukungan terhadap penggarapan KB di seluruh RW yang ada di Kelurahan; penyuluh KB dan Pembantu Pembina KB beserta berbagai Kelompok Kegiatan dan Kader yang ada di RW menjadi fokus penelitian; model yang menjadi pengamatan adalah interaksi antara Penyuluh KB dengan PPKB-RW, dan PPKB-RW dengan Kader dari berbagai Kelompok Kegiatan di RW beserta Keluarga Sasaran.

Usulan model interaksi tim pengelolaan KB lini lapangan diturunkan ke tingkat Kelurahan dengan harapan bahwa pelayanan KB yang semakin dekat dengan masyarakat akan semakin efektif. Kemudian dengan memanfaatkan potensi masyarakat itu sendiri turut serta dalam pengelolaan dan pelaksanaan program KB di lingkungannya diharapkan dapat mengoptimalkan penggarapan KB lini lapangan. Upaya ini adalah menyusun kembali suatu "model interaksi yang disempurnakan” (MIDI). Konsep dasar model interaksi yang disempurnakan tersebut dibangun berdasarkan konsep pemberdayaan, koordinasi, pendampingan, pembiayaan melalui swadaya masyarakat dan Pemda DKI Jakarta. 


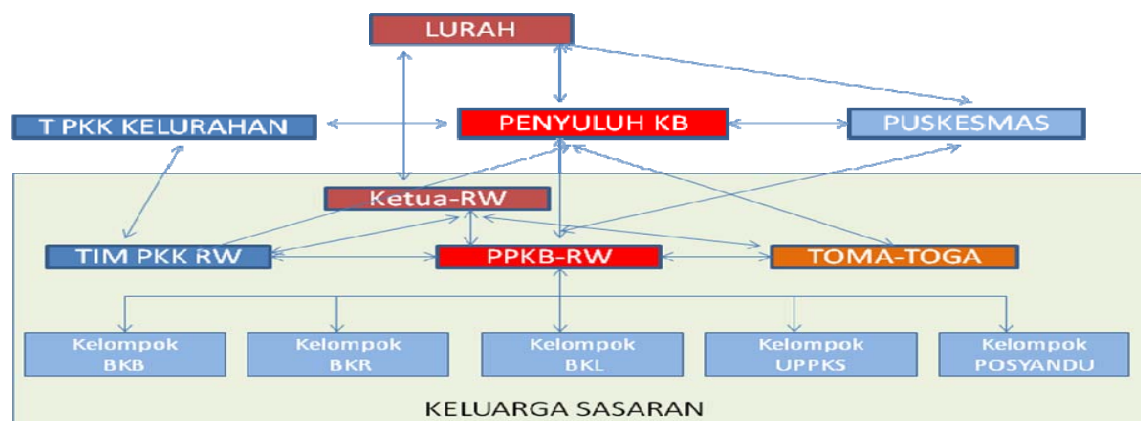

Gambar 1 Model Interaksi yang Disempurnakan: Tim Pengelola KB Lini Lapangan

Model di atas memperlihatkan Lurah sebagai Ketua Tim Pengelola KB Kelurahan bersama Penyuluh KB, Tim Penggerak PKK Kelurahan, dan Puskesmas Kelurahan. Peranan masing-masing sebagai berikut: Lurah selaku Ketua Tim Pengelola KB Kelurahan berperan mengoordinasikan perencanaan, pelaksanaan dan evaluasi Program KB di Kelurahan; Penyuluh KB membantu Lurah melaksanakan koordinasi perencanaan, pelaksanaan dan evaluasi Program KB di Kelurahan; Ketua Tim Penggerak PKK melaksanakan penyuluhan dan motivasi KB melalui Tim PKK RW, Posyandu dan Kelompok-Kelompok Kegiatan; Kepala Puskesmas Kelurahan mengoordinasikan pelayanan medis Keluarga Berencana di Puskesmas maupun di luar Puskesmas; Seluruh PPKB-RW Kelurahan melaksanakan kegiatan sepuluh perannya dalam penggarapan KB di lingkungan RW masing-masing.

Sedangkan peran Penyuluh KB yang secara operasional bertanggung jawab kepada Lurah tetap melaksanakan sepuluh langkah penyuluh KB dalam penggarapan KB di Kelurahan. Peran yang hampir sama dilakukan oleh PPKB-RW di tingkat RW yang secara langsung mengonsultasikan kegiatannya kepada Ketua RW dan kepada berbagai institusi masyarakat yang ada di RW, serta mengoordinasikan pelaksanaan kegiatan kelompok-kelompok kegiatan dalam menggarap KB di lingkungan RW.

\section{Intervensi Penggarapan KB Lini Lapangan}

\section{Pembekalan PPKB RW}

Untuk melaksanakan uji coba peran alternatif PPKB-RW terlebih dahulu dilakukan pembekalan berupa orientasi pada pertemuan PPKB-RW. Kesepakatan dengan Penyuluh KB bahwa pertemuan itu baru dapat dilaksanakan hari Selasa, 7 Februari 2012, dan dalam pertemuan itu Penyuluh memberikan pembekalan kepada PPKB-RW khususnya menyangkut kegiatan-kegiatan: konsultasi dengan Ketua RW dan Ketua RT; koordinasi dengan Institusi Masyarakat lainnya seperti PKK RW, Posyandu, Jumantik, Tokoh Masyarakat dan Tokoh Agama yang ada di lingkungan RW; mengoordinasikan pertemuan dengan Kelompok Kegiatan (Poktan) BKB, BKR, BKL, UPPKS, dan Posyandu (menggalang kesepakatan); melaksanakan kunjungan rumah bersama-sama kader Poktan; melakukan penerangan perorangan maupun kelompok; melaksanakan updating data keluarga; melaksanakan pelayanan KB di RW maupun mendampingi calon akseptor ke Puskesmas dan Rumah Sakit.

\section{Penyusunan Rencana Intervensi Penggarapan KB Februari s/d Juni 2012}

Melihat kalender tahun 2012, bahwa bulan Juli adalah bulan Puasa dilanjutkan dengan Hari Raya Idul Fitri, kemudian bulan Augustus-September adalah Pemilihan Gubernur DKI Jakarta, maka kurun Februari hingga Juni 2012 (5 bulan) adalah waktu yang tepat dilakukan intensifikasi penggarapan KB di RW. Tim Peneliti bersama PPLKB Kecamatan Palmerah dengan dua orang 
Penyuluh KB Kelurahan Kemanggisan menyepakati perlu dilakukan intervensi berupa intensifikasi penggarapan KB di Kelurahan Kemanggisan. Oleh sebab itu, Penyuluh KB dalam pertemuan dengan para PPKB RW01-RW09 pada minggu kedua menyampaikan perlunya kesepakatan intensifikasi penggarapan KB, dengan melakukan kunjungan rumah dan mengajak PUS yang belum ber-KB untuk ber-KB sekaligus melaksanakan updating data keluarga tahun 2012 yang dimulai awal Februari 2012. Pertemuan berikut Penyuluh dengan PPKB-RW pada Kamis, 9 Februari 2012 mulai pukul 09.00 dan selesai pukul 11.30 WIB. Catatan peneliti tentang kesepakatan Penyuluh KB dengan PPKB-RW sebagai berikut: penyuluh KB akan segera mendistribusikan formulir pendataan; Kegiatan kunjungan rumah sudah dapat mulai dilaksanakan pada Minggu ketiga bulan Februari; penyuluh membuat surat resmi dari Lurah ke para Petua RW01 s/d 09; masing-masing PPKB-RW melaksanakan pertemuan dengan para Kader di RW sambil menjelaskan tahapan kegiatan kunjungan rumah, updating data keluarga dan pelayanan pada Minggu ketiga itu juga; PPKB-RW menyampaikan jadwal kegiatan setelah ada kesepakatan dengan Kader; melaksanakan kunjungan rumah bersama Kader; Menyampaikan jadwal pelayanan KB di masing-masing RW dan Puskesmas Kelurahan; bagi RW yang jauh dari Puskesmas maka PPKB-RW menyiapkan tempat pelayanan IUD, Implant, Suntikan KB dan Pil KB pada tempat yang dianggap steril bagi pelayanan KB dan yang biasanya sudah mendapat rekomendasi dari Puskesmas; Penyuluh KB mempersiapkan tenaga medis dan alat/obat kontrasepsi KB yang melayani di RW; PPKB-RW mendampingi calon akseptor ke Puskesmas; apabila updating data belum sepenuhnya dapat diselesaikan pada bulan Juni, maka akan dilanjutkan setelah selesai Pilgub (September 2012), sehingga selesai Oktober 2012; semua biaya pelayanan KB ditanggung oleh Pemda DKI Jakarta dengan mekanisme reimbursement.

\section{Pengamatan Lapangan Kunjungan Rumah}

Langkah pertama Penyuluh KB adalah wajib melakukan kunjungan rumah, demikian halnya PPKB-RW mengawali kegiatannya dengan kunjunan rumah. Penyuluh KB bersama peneliti pada hari Senin, 20 Februari 2012 berkesempatan melihat secara langsung kegiatan kunjungan rumah sekaligus melakukan penerangan individu yang dilakukan PPKB-RW dan Kader kepada PUS di RW06 Kelurahan Kemanggisan. Kegiatan dimulai pukul 09.00 pagi berkumpul di sekretariat RW setelah ibuibu Kader menyelesaikan kegiatan rutin pagi hari di rumah masing-masing. Kunjungan rumah pada hari itu dibagi menjadi dua kelompok. Masing-masing kelompok mengunjungi satu RT yang dibekali dengan copy arsip hasil pendataan tahun sebelumnya dengan satu set formulir kosong untuk mencatat perubahan data keluarga dan tambahan keluarga baru serta mencoret keluarga yang telah pindah rumah. PUS yang belum ber-KB yang ber-KB dicatat dengan kontrasepsi yang dikehendaki, mengingatkan ulangan Suntik KB (bulanan) dan persediaan Pil KB Ulangan.

Dari hasil kunjungan rumah terhimpun calon peserta KB yang dilayani hari itu sebanyak 22 peserta IUD $=4$ orang, Implant $=4$ orang, Suntikan $\mathrm{KB}=14$ orang. Kunjungan rumah berakhir pukul 14.00 WIB, dan calon akseptor diputuskan dilayani di Puskesmas Kelurahan Kemanggisan besok harinya, Selasa 21 Februari 2012. Kemudian kunjungan rumah berikutnya akan dilaksanakan pada hari Kamis, 23 Februari 2012. Diperkirakan kunjungan rumah akan selesai pada bulan Mei 2012 meliputi 16 RT, termasuk mengunjungi ulang Keluarga yang tidak ditemukan dirumah pada saat kunjungan pertama.

Ibu Neneng Maryati, PPKB RW08 yang ditemui secara terpisah, mengatakan bahwa di RW08 juga telah disepakati kunjungan rumah untuk melakukan pendataan sekaligus menjaring calon akseptor. Menurut perkiraannya calon akseptor yang akan dilayani akan masih cukup banyak, terutama yang ganti cara dari kontrasepsi sederhana Suntikan dan Pil menjadi IUD dan Implant. Beliau menambahkan bahwa di lingkungan RW08 ada rumah warga yang memenuhi syarat sebagai tempat pelayanan KB yang steril, kebetulan pemilik rumah juga Kader Posyandu, dan pelayanan KB di rumah itu sudah biasa dilakukan, sarananya lengkap termasuk adanya gynecology bed. Sedangkan peralatan sterilisasi peralatan medis, kontrasepsi, dan obat, serta bahan habis pakai akan dibawa 
petugas medis pada hari pelayanan. Peneliti berketepatan ingin melihat pertemuan kader kelompok kegiatan yang direncanakan dilaksanakan di RW08.

\section{Pengamatan Pembinaan Kader Kelompok Kegiatan oleh PPKB-RW}

Jumlah Pengurus dan Kader Kelompok kegiatan (BKB, BKR, BKL, UPPKS, Posyandu) yang hadir pada pertemuan di Sekretariat RW08 Kelurahan Kemanggisan sebanyak 26 orang. Di antaranya ada kader yang merangkap di dua kelompok kegiatan, misalnya seorang kader Bina Keluarga Balita merangkap sebagai Kader Posyandu. Merangkap kader dianggap sebagai hal yang tidak memberatkan mereka karena kegiatan kelompok itu hanya masing-masing sekali sebulan. Pertemuan dilaksanakan pukul 09.00 WIB pagi, malahan Bapak Ketua RW turut hadir dan membuka acara dan memperkenalkan Peneliti dan Penyuluh KB. Kemudian PPKB-RW mempersilahkan Penyuluh KB memberikan arahan, kemudian dilanjutkan oleh PPKB-RW penjelasan tehnis tentang kegiatan yang akan dilaksanakan yaitu pendataan berupa sweeping dari rumah ke rumah dan pelayanan KB. Penyuluh KB menyampaikan formulir pendataan kepada PPKB-RW, kemudian setelah selesai pengarahan dan penjelasan teknis, dilanjutkan tanya jawab dan suasana langsung berubah menjadi nonformal. Peneliti mengamati bahwa ada air mineral dalam plastik dibagikan bersama snack. Pertemuan berlangsung mulai pukul 09.00 sampai selesai pukul 11.00 WIB kemudian acara ditutup oleh PPKB-RW.

\section{Pengamatan Pelayanan KB di Puskesmas}

Pelayanan KB di Puskesmas merupakan pelayanan rutin terhadap calon peserta KB baru meminta pelayanan sesuai dengan metode yang dikehendaki maupun peserta KB itu sendiri datang ke Puskesmas untuk konsultasi. Adapun metode/cara KB yang dapat dilayani di Puskesmas seperti: untuk wanita IUD (intra uterine device), Implant (alat KB yang dipasang dibawah kulit lengan), Suntikan KB (bulanan) dan Pil KB, sedangkan untuk Pria disediakan Kondom. Metode Operasi Wanita/MOW (tubectomy) dan Metode Operasi Pria/MOP (vasectomy) hanya boleh dilayani pada Rumah Sakit, dan khusus MOP dapat dilayani di Mobil Unit Pelayanan KB Keliling sebagai bagian dari Klinik KB Rumah Sakit.

Setelah pendaftaran dan mendapat nomor, maka calon akseptor dipanggil menemui petugas konseling. Petugas konseling mengisi formulir K/IV/KB, kemudian akseptor yang sudah dilayani mendapat Kartu K/I/KB untuk disimpan dan dibawa pada saat pemeriksaan ulang, mendapat suntikan bulanan ulangan atau pil ulangan. Pada umumnya calon peserta KB menerima konseling lebih dahulu tentang alasan dan pilihan metode, pemeriksaan kesehatan, dan petugas medis yang memutuskan jika calon peserta KB tersebut dapat dilayani sesuai metode/cara KB yang diminta calon akseptor, atau menganjurkan pemakaian kontrasepsi tertentu sesuai dengan keadaan kesehatan, umur, paritas (jumlah anak yang dimiliki). Jika hanya sekedar menjarangkan atau menunda kehamilan, ditawarkan menggunakan metode sederhana seperti Suntikan KB, Pil KB, dan Kondom. Namun jika calon memiliki jumlah anak yang sudah cukup dan tidak ingin menambah anak lagi, dianjurkan memakai kontrasepsi jangka panjang (IUD, Implant) atau Kontrasepsi Mantap (MOW dan MOP). Jika dokter atau bidan melakukan insertie IUD hanya sekitar 5 menit per akseptor; namun jika memasang implant rata-rata memerlukan waktu 20 menit hingga 30 menit per akseptor.

Pelayanan Suntikan KB relatif lebih cepat demikian halnya pemberian Pil KB termasuk menjelaskan waktu dilakukan suntikan ulangan dan pemberian pil ulangan. Dalam waktu normal Puskesmas menerima rata-rata 5 hingga 10 akseptor per hari pelayanan. Namun jika ada pemberitahuan oleh Penyuluh KB maupun PPKB-RW yang membawa calon akseptor ke Puskesmas, jumlah akseptor yang dilayani bisa mencapai 20 hingga 25 akseptor. Pada saat pengamatan di Puskesmas Kemanggisan, Selasa 21 Februari 2012, dilayani 2 peserta IUD, 2 peserta Implant, dan 5 peserta KB suntikan serta 3 peserta yang menggunakan Pil, sehingga jumlah peserta KB baru yang 
dilayani mulai pukul 08.00 hingga pukul 11.00 sebanyak 12 akseptor baru, sebagai hasil sweeping sehari sebelumnya.

\section{Pengamatan Pelayanan KB di RW}

Pada Rabu, 22 Februari 2012 mulai pukul 09.00 telah dimulai pelayanan KB di salah satu rumah Kader, yang fasilitas ruangan dan peralatan cukup memadai dan steril. Ada dua orang bidan datang dari Puskesmas Kemanggisan sekalius membawa sterilisasi kit untuk peralatan pelayanan, kontrasepsi dan obat/bahan habis pakai. Calon peserta KB hari itu sebanyak 12 orang, yang terdiri dari Calon IUD $=6$ orang, implant $=4$ orang, dan selebihnya sebanyak 12 calon peserta suntikan $\mathrm{KB}$, semua selesai dilayani pukul 11.00 WIB. Prosesnya sama seperti pelayanan di Puskesmas. PPKB-RW juga menyediakan minuman mineral dan kudapan untuk calon akseptor maupun paramedis dan kader. Satu hal dalam pengamatan penulis, bahwa para kader sepertinya sudah biasa mengerjakan pekerjaan mereka, menjemput akseptor, menyediakan minuman, menulis kartu K/IV mengenai karakteristik calon akseptor, menulis K///KB yaitu Kartu Akseptor KB, memberikan obat antibiotik, vitamin, membersihkan peralatan medis dengan sterilisasi, tanpa ada perintah, tanpa melihat pedoman. Dokter dan bidan yang datang kelihatannya sudah akrab dengan pemilik rumah, satu kamar tertutup dengan rushbank, ada meja menempatkan peralatan, colokan lampu, dan washtafel.

\section{Pengamatan Kelompok UPPKS sebagai Upaya Pemberdayaan Ekonomi Keluarga}

Berdasarkan pengamatan dan wawancara dengan Penyuluh KB maupun dengan PPKB-RW, bahwa perkembangan Usaha Peningkatan Pendapatan Keluarga Sejahtera relatif stagnan, tidak ada perkembangan yang signifikan. Jumlah Kelompok UPPKS makin berkurang, jumlah modal tidak bertambah dari jumlah bantuan modal yang diserahkan oleh BPMPKB DKI Jakarta. Pemberian bantuan modal itu adalah untuk modal awal dan diharapkan kelompok dapat mengembangkannya. Jumlah bantuan modal awal per kelompok hanya Rp.5 juta, sedangkan anggota kelompok sekitar 20 ibu. Di Kelurahan Kemanggisan terdapat lima Kelompok UPPKS, dan di Kelurahan Pulogebang sebanyak enam kelompok yang beruntung memperoleh bantuan modal.

Penyerahan bantuan modal kelompok itu bervariasi sejak 2005 hingga 2011 yang lalu. Jumlah kelompok bertambah di DKI Jakarta, namun kualitas kelompok tidak kunjung berkembang. Sebelum penyerahan bantuan modal tersebut, dilakukan orientasi kepada para pengurus kelompok di Kecamatan. Kemudian pembinaan kelompok dilanjutkan oleh Penyuluh KB bersama PPKB yang bersangkutan.

Profil kelompok UPPKS di RW08 yang diketuai oleh Ibu Neneng Maryati yang anggotanya sebanyak $20 \mathrm{ibu}$, lebih menitikberatkan pemakaian pinjaman modal pada anggotanya untuk kegiatan usaha secara perorangan. Pernah sepuluh tahun lalu (2002) Ketua UPPKS mengupayakan supaya ada kegiatan produktif kelompok. Pilihan usaha kelompok waktu itu adalah membuat kue kering dan melayani pesanan kue basah dengan peralatan yang dimiliki oleh para anggota kelompok. Pendapatan tertinggi pada waktu itu bisa mencapai lebih dari Rp.25 juta dalam bulan Desember 2002. Kemudian tahun lalu (2011) kegiatan membuat kue diaktifkan lagi. Kue kering tersebut dikemas dalam tupperware plastic tertutup, diberi merek, dan disalurkan ke toko-toko kue dan toko kelontong sekitar Kemanggisan dan Pasar Palmerah. Pada awalnya usaha ini berjalan lancar terutama karena menjelang Lebaran dan Natal, sehabis kedua momen itu usaha tersebut kembali lesu dan tidak bangkit lagi, yang kemudian dilanjutkan oleh satu-dua anggota secara perorangan. Para anggota meminjam modal ke kelompok berkisar Rp.200.000 s/d Rp.500.000.

Tidak dapat dipungkiri bahwa sebagian ibu-ibu anggota meminjam untuk kebutuhan seharihari karena sebagian besar keluarga anggota bekerja serabutan yang pendapatannya tidak menentu. Memang pinjaman modal tersebut adalah untuk keluarga pra-sejahtera (miskin). Lamanya peminjaman hanya sebulan agar anggota lainnya mendapat kesempatan terutama untuk memenuhi 
kebutuhan dapur yang mendesak karena tidak memperoleh pendapatan pada hari itu. Catatan terakhir Juni 2012, saldo Kelompok ini tercatat Rp.7.875.000,-, karena memang tidak dikenakan bunga, hanya sekedar kerelaan anggota peminjam memberikan lebih dari jumlah uang yang dipinjam. Upaya menambah modal kelompok telah dilakukan antara lain melalui Kantor Lurah dan Camat yang dapat mengajukan melalui Musrenbang Kelurahan dan Kecamatan. Tambahan modal itu diharapkan dibiayai melalui APBD dalam bentuk hibah, dan sampai saat ini belum berhasil.

\section{Hasil Intervensi}

Perbandingan Hasil Pencapaian Peserta KB Baru di Kelurahan Kemangisan (dengan intervensi) dengan Kelurahan Pulogebang (tanpa intervensi) menunjukkan ada perbedaan. Pelayanan KB selama lima bulan (Februari-Juni 2012) di Kelurahan Kemanggisan dengan intervensi mampu menyelesaikan target peserta KB baru tahun 2012 berdasarkan perkiraan permintaan masyarakat yang diperoleh dari data keluarga yang dihimpun pada pendataan keluarga tahun sebelumnya (2011). Pencapaian tersebut dilayani di Puskesmas Kelurahan Kemanggisan dan Pelayanan di RW.

Tabel 2 Pencapaian Peserta KB Baru Februari s/d Juni 2012

di Kelurahan Kemangisan, Palmerah, Jakarta Barat

\begin{tabular}{lrrrrrrrr}
\hline $\begin{array}{c}\text { Metode } \\
\text { Kontrasepsi }\end{array}$ & Feb & Mar & Apr & Mei & Jun & $\begin{array}{c}\text { Pencapaian } \\
\text { Peserta KB Baru }\end{array}$ & $\begin{array}{c}\text { Target PPM } \\
\text { 2012 }\end{array}$ & \%/PPM \\
\hline Pil & 42 & 130 & 137 & 88 & 63 & 460 & 790 & 108,5 \\
Suntikan & 195 & 213 & 145 & 102 & 135 & 57 & 786 & 100,5 \\
Kondom & 12 & 7 & 12 & 13 & 13 & 101 & 43 & 132,5 \\
IUD & 13 & 15 & 27 & 16 & 30 & 74 & 99 & 102 \\
Implant & 12 & 16 & 15 & 16 & 15 & 11 & 46 & 160,8 \\
MOP* & 3 & 1 & 2 & 2 & 3 & 13 & 11 & 100 \\
MOW** & 3 & 2 & 4 & 1 & 3 & 1507 & 12 & 108,3 \\
Total & 281 & 384 & 342 & 238 & 262 & & 1421 & 106,05 \\
\hline
\end{tabular}

*Dilayani di Mobil Unit Pelayanan KB

** Dilayani di Rumah Sakit

Sumber : F/II/KB bulan Juni 2012 Puskesmas Kelurahan Kemanggisan

Jumlah Perkiraan Permintaan Masyarakat (PPM) tahun 2012 di Kelurahan Kemanggisan sebesar 1421 Peserta KB Baru dapat diselesaikan dalam 5 (lima) bulan sebanyak 1507 peserta KB baru atau 106,05 dari target PPM. Kehadiran tim peneliti di beberapa lokasi mendampingi kegiatan ibu-ibu PPKB-RW di Kelurahan Kemanggisan disambut dengan penuh kekeluargaan. Kemudian karena ibu-ibu itu sadar merasa diteliti dan ditemani, sehingga melakukan upaya yang lebih dari biasanya melakukan penerangan dan motivasi tatap muka secara individu maupun kelompok kepada PUS yang belum ber-KB sebagai calon akseptor. Sehingga terlintas dalam pemikiran peneliti bahwa Kader yang termotivasi karena kehadiran Penyuluh dan Tim Peneliti sedang melakukan motivasi kepada calon akseptor, hasilnya akan lebih dari biasanya. Lebih dari itu calon akseptor yang yang datang sendiri ke Puskesmas pada bulan Juli, Augustus, dan September tetap akan dilayani sebagaimana biasa. Kemudian pada bulan Oktober, November, dan Desember tetap akan ada pelayanan KB di Puskesmas, sehingga diperkirakan sampai akhir Desember 2012 akan dapat mencapai target PPM sekitar 150\%.

Sebagai perbandingan, diperoleh hasil pencapaian Peserta KB Baru dari Kelurahan Pulogebang (tanpa intervensi) sebagaimana disajikan dalam tabel berikut ini. 
Tabel 3 Pencapaian Peserta KB Baru Februari s/d Juni 2012 di Kelurahan Pulogebang, Cakung, Jakarta Timur

\begin{tabular}{lrrrrrrrrr}
\hline $\begin{array}{c}\text { Metode } \\
\text { Kontrasepsi }\end{array}$ & Feb & Mar & Apr & Mei & Jun & $\begin{array}{c}\text { Pencapaian } \\
\text { Peserta KB Baru }\end{array}$ & $\begin{array}{c}\text { Target PPM } \\
\text { 2012 }\end{array}$ & $\begin{array}{c}\text { \%Penc/Target } \\
\text { PPM }\end{array}$ \\
\hline Pil & 87 & 77 & 72 & 91 & 80 & 407 & 435 & 93,50 \\
Suntikan & 57 & 41 & 48 & 45 & 43 & 234 & 285 & 82,10 \\
Kondom & 22 & 12 & 20 & 18 & 20 & 92 & 110 & 83,64 \\
IUD & 38 & 31 & 29 & 40 & 33 & 171 & 190 & 90,00 \\
Implant & 10 & 4 & 3 & 15 & 12 & 44 & 50 & 88 \\
MOP* & 2 & 0 & 1 & 1 & 1 & 5 & 5 & 5 & 50 \\
MOW** & 1 & 0 & 2 & 1 & 1 & 952 & 1085 & 87,74 \\
Total & 217 & 165 & 169 & 211 & 190 & & 500
\end{tabular}

*Dilayani di Mobil Unit Pelayanan KB

** Dilayani di Rumah Sakit

Sumber: F/II/KB bulan Juni 2012 Puskesmas Kelurahan Pulogebang

Perbandingan kedua Kelurahan terlihat dari segi persentase pencapaian Peserta KB Baru bulan Februari s/d Juni 2012 di Kelurahan Kemanggisan lebih tinggi dibanding pencapaian Kelurahan Pulogebang (tanpa intervensi). Penyuluh KB dengan Peneliti melakukan intervensi secara terbuka di Kelurahan Kemangisan melalui pertemuan penyusunan rencana dengan pembekalan Penyuluh KB kepada PPKB RW. Namun berdasarkan pencapaian peserta KB baru di Kelurahan Pulogebang hingga Juni 2012 tersebut, dapat diprediksi juga akan mampu melebihi seratus persen target PPM.

\section{Model Interaksi Pengelolaan KB Kecamatan Versus Pengelolaan KB Kelurahan}

Setelah mengetahui luasnya wilayah dan jumlah penduduk, jumlah keluarga dan jumlah Pasangan Usia Subur per kecamatan di DKI Jakarta yang menjadi sasaran pelaksanaan Program KB, maka timbul keinginan untuk merevitalisasi pengelolaan KB tersebut dengan maksud mengefektifkan pelaksanaan KB lini lapangan. Jika lini lapangan yang selama ini diangap mulai dari kecamatan ke masyarakat, maka jaraknya cukup jauh padahal struktur Pemerintahan di DKI Jakarta sampai di kelurahan. Perangkat Pemerintahan di kelurahan dianggap memadai apabila semua aspek pembangunan telah tercakup di dalamnya. Penyuluh KB ditempatkan di Kelurahan yang bertanggung jawab secara administratif kepada PPLKB Kecamatan dan secara operasional kepada Lurah.

Pada Kelurahan sasaran pengamatan yaitu Kelurahan Kemanggisan dan Pulogebang masingmasing sudah ada dua orang Penyuluh KB. Pendidikan Penyuluh KB pada umumnya S1, menyandang jabatan fungsional Penyuluh dan telah bekerja lebih dari 15 tahun. Tugas pokok penyuluh KB dirumuskan menjadi sepuluh langkah penyuluh KB mulai kunjungan rumah hingga pencatatan pelaporan.

Pemikiran agar Tim Pengelola KB Kelurahan lebih diefektikan untuk mendekatkan pelayanan kepada masyarakat cukup beralasan, karena perangkat di kelurahan di DKI Jakarta sudah cukup memadai, antara lain adanya Puskesmas Kelurahan, institusi masyarakat ditingkat RW dan RT sudah cukup mapan, keberadaan kelompok-kelompok kegiatan yang keberadaannya lebih dari 10 tahun, dan jumlah kader masyarakat yang dapat digerakkan juga jumlahnya cukup banyak. Keuntungan keberadaan institusi masyarakat dan kelompok-kelompok kegiatan akan menjadi jaringan KB yang operasional jika dibina lebih intensif.

\section{Institusi Masyarakat Pembantu Pembina KB RW}

Sebenarnya keberadaan PPKB-RW telah dimulai sejak tahun 1970-an, sehingga tidak mengherankan jika masih ada PPKB-RW yang aktif lebih dari 30 tahun. PPKB-RW tersebut dikrekrut dari kalangan ibu-ibu yang memiliki keinginan mengabdi kepada masyarakat lingkungan. Di 
antaranya ada juga sebagai kader PKK dan berbagai kelompok kegiatan lainnya. Penunjukan dan pembentukan PPKB RW melalui pengamatan yang mendalam oleh para Penyuluh yang ada di Kelurahan tersebut sebelum memutuskan siapa di antara ibu-ibu tersebut yang diangap memenuhi syarat.

Adapun syarat-syaratnya adalah minimal lulus SD, bisa baca-tulis, kader yang sudah aktif di masyarakat, dan memiliki pengabdian yang tulus kepada masyarakat lingkungannya. Pada awalnya dalam satu RW ada beberapa ibu yang dianggap memenuhi syarat dan kemudian dibentuk kepengurusan: Ketua, Sekretaris, Bendahara, dan Anggota. Belakangan, yang menonjol memang adalah figur ketua PPKB-RW tersebut. Dalam perkembangan berikut dikenal hanya perorangan yaitu ketua, kemudian para pengurus lain diaktifkan membentuk dan membina berbagai kelompok kegiatan di RW tersebut yang menyangkut dan terkait dengan Program KB seperti Kelompok Bina Keluarga Balita (BKB), Kelompok Bina Keluarga Remaja (BKR), Kelompok Bina Keluarga Lansia (BKL), dan Kelompok Usaha Peningkatan Pendapatan Keluarga Akseptor (UPPKA) yang berubah menjadi Kelompok Usaha Peningkatan Keluarga Sejahtera (UPPKS). Semua kelompok tersebut lengkap dengan kepengurusan dan anggota. Kelompok-kelompok kegiatan tersebutlah yang menjadi jaringan yang efektif dalam penggarapan program KB di RW.

\section{Pola Penggarapan Program KB di RW}

PPKB-RW sebagai koordinator KB di tingkat RW telah mampu melaksanakan tugas sepuluh langkah pengarapan KB mulai dari: kunjungan rumah, penerangan dan motivasi, pelayanan $K B$, pendekatan tokoh, pendataan, pemetaan, menyalurkan kontrasepsi ulangan, membina kelompokkelompok kegiatan, melakukan koordinasi dan pencatatan pelaporan. PPKB-RW tidak bekerja sendiri melainkan dibantu oleh seluruh kader Kelompok-Kelompok Kegiatan yang ada di RW. Di lingkungan warga masyarakat sendiri sosok PPKB-RW tersebut sudah dianggap sebagai tokoh masyarakat di lingkungan RW tersebut, karena selain dikenal luas, mereka juga sudah mapan segi ekonomi maupun sosial. Proses penunjukkan mereka sebagai Ketua PPKB-RW antara lain karena dianggap dapat menjadi panutan di lingkungan masyarakat sekitar, sebagai tokoh yang dihormati, selain pendidikan yang memadai dan aspek lainnya.

Keberadaan PPKB-RW yang sudah sejak lama menjadikan para Ketua RW merasa wajib mendukung kegiatan para PPKB-RW untuk kepentingan dan kebutuhan warga, bahkan oleh seluruh Ketua RT. Sama dengan keberadaan Posyandu yang sangat didukung oleh semua pihak dan warga yang ada di RW. Hal ini terbukti dari rapat persiapan di RW, kemudian melaksanakan aksi sesuai kesepakatan dengan para kader, mulai dari kunjungan rumah yang sekaligus melakukan pendataan dan penerangan motivasi kepada keluarga, menjaring calon akseptor, keluarga Balita, keluarga Remaja dan Keluarga Lansia serta keluarga Pra-sejahtera. Pelayanan KB yang unik di lapangan dengan memilih satu tempat atau rumah kader yang dianggap steril dapat dilaksanakan dengan efektif. Adanya link antara PPKB-RW dengan Puskesmas Kelurahan mempermudah pelaksanaan pelayanan di Puskesmas Kelurahan apabila pelayanan dilaksanakan di Puskesmas, dan kehadiran petugas medis Puskesmas ke RW jika pelayanan dilakukan di RW.

\section{Pelayanan KB di RW}

Kalau beberapa dekade sebelumnya sekitar 1980 sampai 1990-an sangat marak pelayanan KB di lapangan. Misalnya, gedung sekolah SD, Gelanggang Remaja, Aula, kantor Kecamatan, disulap menjadi tempat pelayanan IUD dan Implant, Suntikan KB bahkan Medis Operasi Pria dan pelayanan kesehatan umum lainnya dalam operasi kegiatan secara massal, bakti sosial, Manunggal TNI-KBKesehatan, dsb. Pemerintah pada saat itu menjadikan Keluarga Berencana sebagai prioritas dalam menghadapi pertumbuhan penduduk alami maupun kemiskinan. Semua pihak terlibat dalam operasi seperti itu termasuk TNI, Polri, Ikatan Dokter Indonesia, Ikatan Bidan Indonesia, Perusahaanperusahaan besar dimobilisasi sedemikian rupa untuk mencapai target penurunan tingkat fertilitas dan 
kelahiran dengan slogan "dua anak cukup”. Kegiatan massal seperti itu semakin dikurangi menimbang faktor strerilisasi lingkungan, selain kurang manusiawi, sehingga tempat pelayanan semakin selektif, termasuk rumah warga "dibolehkan” jika memenuhi syarat steril tadi.

\section{Pola Koordinasi PPKB-RW}

Setelah menyaksikan kegiatan PPKB-RW sesuai peran, maka kemampuan mengoordinasikan berbagai kelompok kegiatan yang terkait dan mendukung penggarapan KB di Wilayah RW cukup dapat diandalkan. Mulai kemampuan memimpin pertemuan dalam merencanakan kegiatan dan melakukan evaluasi, memberikan pengarahan, dan melaksanakan kegiatan lapangan. Kalau kita berpikir lebih jernih, bahwa jumlah cakupan keluarga sasaran dalam satu RW di DKI Jakarta mencapai sekitar 600 hingga 2.000 keluarga, maka sama dengan cakupan jumlah keluarga di 2 hingga 5 desa di provinsi lain. Peran para Penyuluh KB sampai pada tingkat ini adalah sebagai pembina, pendamping, pengarah, dan fasilitator. Sepuluh langkah Penyuluh KB tersebut dilaksanakan bersama PPKB-RW dengan dibantu oleh seluruh Kader yang ada di RW tersebut.

Persoalan yang dihadapi oleh PPKB-RW menurut pengakuan mereka adalah bahwa dukungan Pemerintah (Pemda DKI Jakarta) masih sangat minim. Mereka memang tidak menuntut honorarium, namun dukungan kegiatan operasional sangat diperlukan. Melalui jalur Ketua RW dari dana swadaya masih dalam perjuangan, karena umumnya Ketua RW memprioritaskan biaya administrasi, rapat RW, keamanan, dan kebersihan lingkungan. Camat dan Lurah juga belum memiliki penghayatan yang jelas terhadap kegiatan PPKB RW, sehingga dianggap hanya sekadar kegiatan sosial kemasyarakatan dengan dukungan swadaya.

\section{Kelompok-Kelompok Kegiatan (Poktan)}

Membentuk kelompok kegiatan seperti BKB, BKR, BKL dan UPPKS adalah pekerjaan yang tidak mudah, karena harus menyeleksi kader, membentuk kepengurusan, orientasi, pelatihan, dan perlu ada fasilitas penunjang. Kemudian setelah terbentuk dan kegiatan sudah mulai dilaksanakkan, maka dalam proses lebih lanjut akan timbul persoalan yang diatasi kelompok itu sendiri. Pengurus kelompok memerlukan pelatihan dan buku pedoman yang dapat dipraktikkan. Dalam kenyataan dalam buku pedoman itu tidak ada petunjuk jika ada persoalan dan masalah muncul. Di sinilah letak pendampingan para Penyuluh KB hadir dan memberikan bimbingan dan advokasi.

Berbagai masalah muncul, yaitu: pertama kelompok Bina Keluarga Balita (BKB) dengan sasaran Keluarga khususnya Ibu Balita agar mengerti dan mandiri membimbing tumbuh kembang putra-putrinya yang masih Balita. Namun kemudian muncul BKB Paud (Pendidikan Usia Dini) yang dalam hal ini Penyuluh KB dan PPKB-RW membantu membidaninya. Sasaran BKB Paud ini justru Balita. Kegiatan BKB Paud didukung pembiayaan penuh dari Pemerintah cq Dikbud, sedang BKB diserahkan pada swadaya masyarakat. Dampak kebijakan ini sangat dirasakan oleh Kelompok BKB yang bersisian dengan BKB PAUD. Selanjutnya jika Balita yang dulu sekarang beranjak remaja, keluarga itu bergeser keanggotaannya masuk kelompok Bina Keluarga Remaja.

Kedua, Bina Keluarga Remaja (BKR) dengan sasaran Keluarga Remaja (orangtuanya) agar mampu membimbing, berkomunikasi dengan putra-putrinya yang masih remaja, memahami kesehatan reproduksi, pergaulan remaja masa kini, bahaya narkoba, bahaya game online, bahaya penyakit menular seksual hingga HIV/AIDS. Kegiatannya adalah diskusi dalam pertemuan bulanan antarkeluarga anggota BKR. Muncul ide dari keluarga-keluarga itu membuat kegiatan bersama, rekreasi, dan refleksi pemahaman keremajaan putra-putri mereka. Kemudian dilakukan kegiatan bersama orangtua dan remaja. Upaya ini juga sangat menonjol pada awalnya, kemudian kelompok ini kehabisan bahan diskusi, dan pertemuan kelompok menjadi mandek. Setelah beberapa tahun kemudian si remaja telah dewasa malah telah menikah dan tinggal terpisah dari orangtua. Semestinya 
berdasarkan hasil pendataan akan selalu ditemukan keluarga yang memiliki anak remaja, sehingga terjadi rekrutmen anggota baru BKR. Demikian selanjutnya mengikuti siklus dan waktu.

Ketiga, Bina Keluarga Lansia (Lanjut Usia)/BKL juga dengan sasaran Keluarga yang dalam rumah tangga itu ada lanjut usia yang memerlukan perhatian dalam interaksi dengan keluarga dan lingkungan, dengan tujuan agar para lanjut usia tersebut merasa berguna bagi lingkungannya. Tidak mudah menciptakan kegiatan kelompok ini selain dari diskusi, yang kemudian kehabisan bahan sehingga memerlukan masukan dari berbagai pihak utamanya Penyuluh KB.

Keempat, Kelompok Usaha Peningkatan Pendapatan Keluarga Sejahtera (UPPKS) adalah kelompok usaha ekonomi produktif dengan para anggota prioritas keluarga pra-sejahtera (miskin). Proses pembentukan kelompok ini berdasarkan data hasil pendataan keluarga, kemudian melakukan pendekatan kepada tokoh, khususnya ibu-ibu untuk bersedia sebagai pengurus dan anggota. Setelah terbentuk segera dilakukan orientasi bahkan pelatihan bagi pengurus yang diikuti penyerahan bantuan modal awal. Kelompok membuat aturan dan tanggung renteng. Karena terbatasnya bantuan modal sedangkan yang membutuhkan dana adalah semua anggota keluarga yang pra-sejahtera, maka jumlah peminjam dan batas jumlah pinjaman serta batas waktu pengembalian ditetapkan bersama. Niat awal adalah agar keluara pra-sejahtera tersebut memulai usaha kecil, namun sebagian pinjaman menjadi konsumtif. Pelatihan bagi anggota kelompok peminjam uang hanya berupa pengarahan ketua kelompok. Respons pemerintah sementara ini agar kelompok ini secara swadaya mencari tambahan modal, atau memupuk modal sendiri.

Keseluruhan kelompok tersebut memiliki kader termasuk anggota pengurus minimal 10 orang, maka potensi ini juga dimanfaatkan oleh PPKB-RW untuk melakukan kegiatan seperti kunjungan rumah dan pendataan, sekaligus meng-update data yang terkait dengan kelompok-kelompok kegiatan tersebut. Karena ada pertemuan rutin, para kader saling memahami berbagai kelompok kegiatan yang ada di RW tersebut, termasuk di dalamnya Posyandu. Kegiatan KB dan Posyandu itu dianggap merupakan kegiatan wajib bersama, sehingga keberadaannya eksis sampai saat ini.

\section{SIMPULAN}

Penggarapan KB di DKI Jakarta masih perlu dilakukan lebih intensif dengan kedudukan tim pengelola lini lapangan yaitu Kelurahan. Peranan Tim Pengelola KB Kecamatan lebih cocok sebagai penggalangan kesepakatan, memfasilitasi, dan mengendalikan kegiatan KB meliputi seluruh Kelurahan yang ada di Kecamatan tersebut. Model interaksi Tim Pengelola KB Kecamatan yang demikian luas perlu semakin disederhanakan menjadi pola model interaksi tim pengelola KB yang disempurnakan di tingkat kelurahan, sehingga penggarapan KB dapat dilaksanakan semakin intensif di lini lapangan. Peran Lurah selaku Ketua Tim Pelaksana KB Kelurahan dibantu oleh Seksi Kesmas Kelurahan, Ka Puskesmas Kelurahan, Ketua Tim Penggerak PKK Kelurahan beserta Penyuluh KB bersama-sama merencanakan kegiatan operasional program KB di wilayah kelurahan tersebut dengan didukung oleh partisipasi masyarakat, mulai Ketua-Ketua RW dan RT, PPKB-RW dan semua kader Kelompok Kegiatan yang ada di RW. Swadaya masyarakat untuk kegiatan Program KB di lingkungan RW masih sangat rendah ketimbang keharusan membiayai kegiatan Keamanan, Kebersihan di RW. Sedangkan dukungan pembiayaan operasional dari Pemerintah bagai tidak menyentuh lini lapangan hingga RW, padahal calon peserta KB sangat jarang yang sadar sendiri dan datang sendiri ke Puskesmas untuk memperoleh informasi KB dan pelayanannya. Semakin intensifnya interaksi Para Penyuluh KB dengan Institusi Masyarakat yang ada di RW diharapkan berdampak meningkatnya kesertaan KB di Wilayah Kelurahan. Institusi Masyarakat beserta berbagai kelompok kegiatan juga bergantung pada ketersediaan fasilitas dukungan operasional yang diperoleh baik dari swadaya masyarakat maupun dukungan fasilitasi dari Pemerintah Daerah Khusus Ibukota Jakarta. Peranan 
Institusi Masyarakat PPKB-RW sebagai koordinator pelaksana KB ditingkat RW melaksanakan peran sepuluh langkah pengarapan KB mulai dari: kunjungan rumah, penerangan dan motivasi, pelayanan $K B$, pendekatanTOMA/TOGA, pendataan, pemetaan, menyalurkan kontrasepsi ulangan, membina kelompok-kelompok kegiatan, menggalang kesepakatan, pencatatan pelaporan dan menggali swadaya partisipasi masyarakat. PPKB-RW tidak bekerja sendiri melainkan dibantu oleh seluruh kader Kelompok-Kelompok Kegiatan yang ada di RW.

\section{Rekomendasi}

Penggarapan program KB di lini lapangan tidak cukup hanya mengandalkan interaksi para Penyuluh KB yang bertugas di Kelurahan dalam melaksanakan sepuluh langkah pendekatan program KB, melainkan harus mengedepankan peranan Lurah selaku Ketua Tim Pelaksana KB Kelurahan yang didukung oleh Institusi Masyarakat dengan fasilitas yang memadai, sehingga melalui penelitian ini direkomendasikan kepada Pemerintah Daerah Khusus Ibukota Jakarta hal-hal sebagai berikut: pertama, meningkatkan peranan Lurah yang selama ini dianggap sebagai Ketua Tim Pelaksana KB Kelurahan menjadi Ketua Tim Pengelola KB Kelurahan yang aktif berperan dalam perencanaan, pengendalian dan evaluasi. Kedua, untuk melaksanakan peran sebagai Ketua Tim Pengelola KB Kelurahan, maka Pemda DKI Jakarta mewajibkan Lurah dan Ketua Tim Penggerak PKK Kelurahan serta Seksi Kesmas Kelurahan untuk mengikuti Pelatihan Program KB Nasional di UPT. Balai Diklat KB Provinsi DKI Jakarta. Ketiga, Pemda DKI Jakarta memberikan dukungan operasional yang memadai bagi Penyuluh KB yang ditempatkan di Kelurahan. Keempat, Pemda DKI Jakarta diharapkan memberikan dukungan dan bantuan operasional kepada PPKB-RW berupa: biaya pertemuan Pengurus dan Kader Kelompok-Kelompok Kegiatan ditingkat RW, bantuan kegiatan operasional pelayanan PPKB di RW, bantuan perlengkapan PPKB-RW, dan pelatihan Program KB bagi PPKB-RW. Kelima, selain itu perlu Pelatihan atau Orientasi bagi Pengurus dan anggota kelompok kegiatan Program BKB, Program BKR, Program BKL dan Program UPPKS yan seluruhnya dapat dilakukan oleh UPT Balai Diklat KB. Keenam, Pemda DKI Jakarta juga sangat penting menyalurkan PNPM berupa Bantuan Modal atau Hibah kepada Kelompok-Kelompok UPPKS yang angggotanya pada umumnya terdiri dari Keluarga Pra Sejahtera dan Keluarga Sejahtera I (Miskin) sebagai upaya pemberdayaan ekonomi keluarga. Ketujuh, perlu adanya Instruksi Gubernur untuk memperbaharui pengelolaan dana swadaya masyarakat yang ada di RW selain memperlancar kegiatan sekretariat RW, Kebersihan dan Keamanan lingkungan RW, juga untuk mendukung kegiatan Institusi Masyarakat seperti PPKB-RW.

\section{DAFTAR PUSTAKA}

Bayer, P., \& Ross, S. L. (2006). Identifying Individual and Group Effects in the Presence of Sorting: A Neighborhood Effects Application. NBER Working Papers 12211, National Bureau of Economic Research, Inc.

Bogdan dan Taylor. (1984). Introduction to Qualitative Reseacrh Methods. New York: Wiley.

Brown, L. D. (2006). Memperkenalkan Teori Interaksi Sosial. Paper disajikan pada pertemuan tahunan American Association Sosiologi, Montreal Convention Center, Montreal, Quebec, Kanada.

Davis, K. (1962). Human Relations at Work. New York, San Francisco, Toronto, London.

Dixon, T. (1996). Communication, Organization Performance. New Jersey: Ablex Publishing Corporation. 
Graham, B. S. (2008). Identifying Social Interactions through Conditional Variance Restrictions. Econometrica, Econometric Society, vol. 76(3), pages 643-660, 05.

Henslin, J. M. (2002). Essential of Sociology: A Down to Earth Approach. Fourth Edition. Boston. . (2002). Sociological Theory. New York: Mc Graw-Hill.

Krauth, B. (2006). Social Interactions in Small Groups. Canadian Journal of Economics. Canadian Economics Association, vol. 39(2), pages 414-433, May.

Moleong, L. J. (2002). Metodologi Penelitian Kualitatif. Bandung: Remaja Rosda Karya.

O’Brien, J. A. (2006). Introduction to Information System/Pengantar Sistem Informasi. Jakarta: Salemba Empat.

Robbins, S.P., Coulter,M., 2005, Management, Eighth edition, Pearson Education,Inc., Upper Sadle River, New Jersey,07458.

Robbins, S. P., Judge, T. A. (2007). Orgaization Behavior. Twelfth Edition. New Jersey: Pearson Education.

Sujono, dkk. (1996). Penelitian Usaha Peningkatan Pendapatan Keluarga Sejahtera (UPPKS) di DKI Jakarta. Jakarta: PSPK ISI DKI Jakarta.

Sunarto, K. (2004). Pengantar Sosiologi. Jakarta: Lembaga Penerbit FE UI.

Yukl, G. A. (2001). Leadership in Organizations. New Jersey: Prentice Hall. 